\title{
イナートガスシステムの解説および低硫黄燃料油焚きボイラーを 想定した新型イナートガススクラバーの開発
}

松 林 広 延**

\section{1. はじめに}

\section{1 イナートガスシステムの概要}

イナートガスシステムは，主として原油タンカーや ケミカルタンカー, プロダクトタンカーに用いられる, 貨物タンク内の可然性ガスにより引火爆発することを 防ぐための防爆装置である。一般的に可燃性ガスは酸 素と混合した状態となった際に，火花などの発火源に より燃焼が生じる. 加えて可燃性ガスの濃度が一定以 上ある場合，急激な熱エネルギーの放出による気体の 温度上昇および圧力上昇により爆発となる. タンカー において，貨物タンク内では積荷である可燃性危険物 （液体）が揮発し，可燃性ガスである炭化水素ガスが 絶えず発生している状態にある. 且つ貨物タンクは密 閉状態であるため, 炭化水素ガスは高濃度となること から，大規模な爆発となる危険性が極めて高い.

しかし燃焼は発火源, 可燃性物質, そして酸素それ ぞれの存在が同時に満たさなければ生じることはない. この 3 要素を燃焼の 3 要素といい, イナートガスシス テムはこの 3 要素における「酸素」を制御し, 燃焼を 防ぐ防爆装置である.

図 1 に炭化水素ガスの燃焼および爆発範囲を示す. 縦軸は炭化水素濃度, 横軸は酸素濃度を示しており, 斜線にて示している範囲が炭化水素ガスの可燃性範囲 である.（a）点にて炭化水素ガスの燃焼に必要な酸 素濃度は約 $11.5 \mathrm{Vol} \%$ 以上であることがわかる。つま り炭化水素ガスがどれだけ高濃度であったとしても， 貨物タンク内の酸素濃度を約 $11.5 \mathrm{Vol} \%$ 以下にするこ とで，引火爆発を防げる可能性が極めて高くなる，そ のため，可燃性危険物を運搬する船には，IMO の国 際海上人命安全条約にて窒素や二酸化炭素などのイナ ートガスを貨物タンクに送り込む防爆装置の搭載が要 求されている.

*原稿受付 平成 31 年 2 月 18 日.

**株式会社カシワテック (東京都港区高輪 4-5-4)

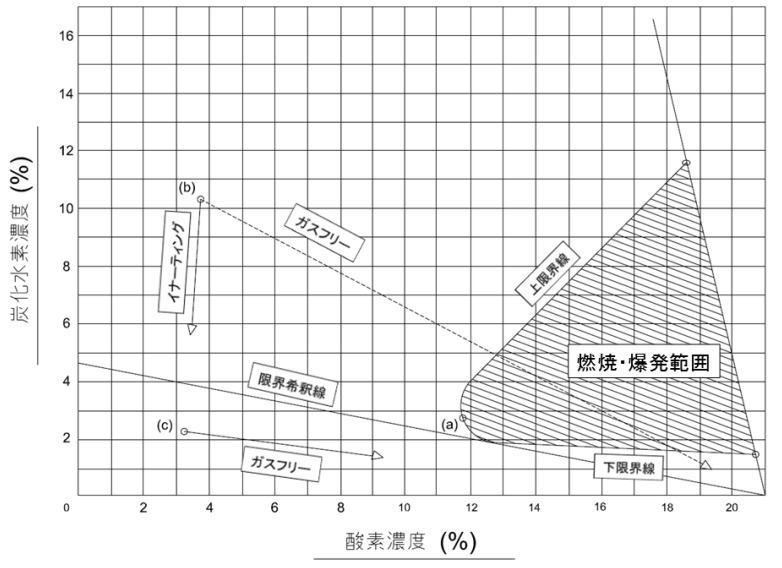

図 1. 炭化水素ガスの燃焼および爆発範囲

\section{2 イナートガスシステムの種類}

イナートガスシステムとはイナートガスを貨物タン クに送り込む防爆装置の総称であり, 複数の種類があ る. 油焚きボイラーの燃焼ガスを利用する「INERT GAS SYSTEM USING BOILER FLUE GAS」, 単 独で燃料油を燃焼させ，よりクリーンなイナートガス を生成する「INERT GAS GENERATOR SYSTEM」, また化学製品の運搬に適した, 大気中の空気から窒素 を分離して利用する「 NITROGEN GAS GENERATOR SYSTEM」がある.

当社は舶用総合消火防災メーカーとして上記全ての ラインナップを有しているが, こと VLCC においては, 原油タンカーであること，またイナートガスの必要量 の多さから INERT GAS SYSTEM USING BOILER FLUE GAS が用いられる. 従って当解説では, INERT GAS SYSTEM USING BOILER FLUE GAS について説明すると共に, 当社イナートガスシス テムにて新たに取り組んでいる, 低硫黄然料油焚きボ イラーを想定したイナートガススクラバーについて説 明する。 


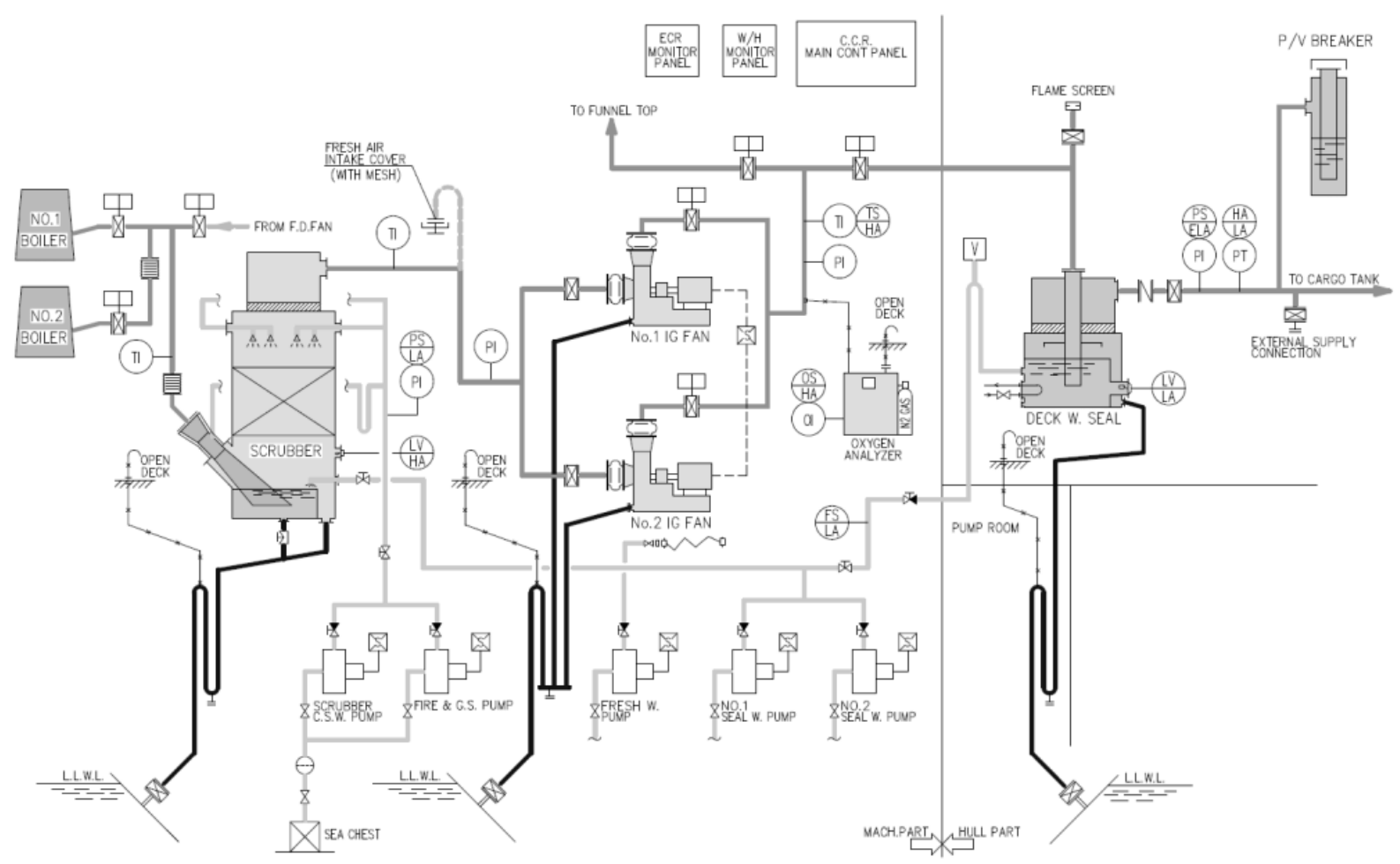

図 2. INERT GAS SYSTEM USING BOILER FLUE GAS 全体像

\section{INERT GAS SYSTEM USING BOILER FLUE GAS}

\section{INERT GAS SYSTEM USING BOILER FLUE}

GAS （以下 IGS）は油焚きボイラーの燃燒ガスを脱 硫，脱鷹，冷却し，生成した不活性ガスを，送風機や 逆流防止装置などを経由して貨物タンクに送る装置全 体の総称である. 図 2 に IGS の全体像を示す. 油焚き ボイラーから出た燃焼ガスはボイラーの煙道からイナ 一トガススクラバーに導かれ，冷却拉よび先浄が行わ れることによりイナートガスが生成される. その後イ ナートガスファンによって送り出されたイナートガス は酸素分析計により酸素濃度が測定されたのち, 甲板 上㳊設置された逆流防止装置であるデッキウォーター シールを通って貨物タンクに放出される。

当社ではこの IGS をIMO 規制が制定された 1970 年当初より先駆的に提供を開始し, 2019 年現在に至る まで 1,900 隻を超える世界中のタンカーへの採用実績 を有している。

\section{1 イナートガススクラバー}

イナートガススクラバーは, ボイラーの排気ガスか ら $\mathrm{SO}_{2}$ や煤を除去するのと同時に, イナートガスとし て使用可能な温度までガスを冷却する装置であり, 主
にプレクーラーおよび充填塔にて構成されている．ボ イラーからの燃焼ガスはプレクーラーに取り込まれ, プレクーラー内で海水と接触することで一次冷却と脱 塵が行われる。 その後ガスは, 充填塔の下部から取り 込まれ上部へ流れ，充填塔の上部から噴霧されている 海水によって $\mathrm{SO}_{2}$ の処理と二次冷却が行われる. 尚, 充填塔内にはガスと洗浄海水との接触効率を高めるた めの充填剤がしきつめられており, $\mathrm{SO}_{2}$ 処理の効率を

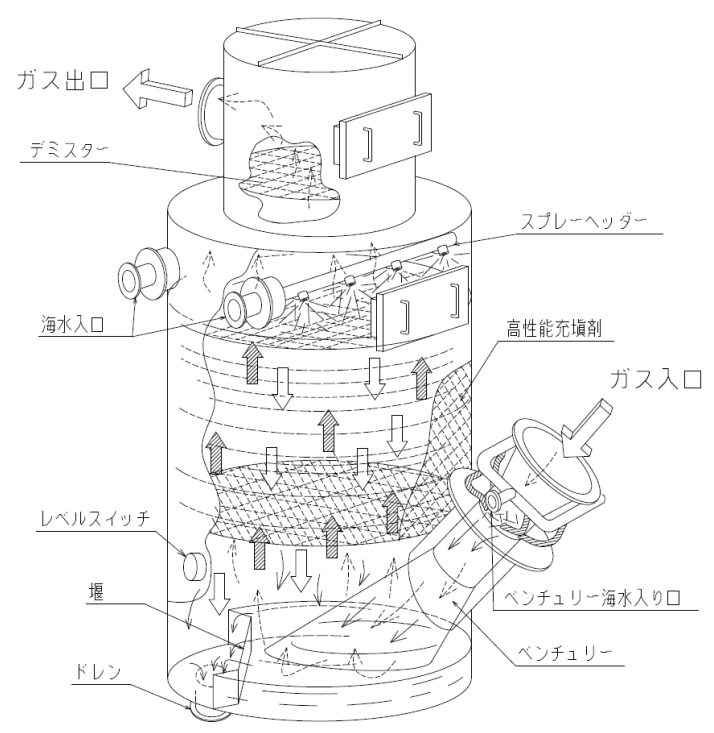

困 3. イナートガススクラバー 
高めている.

当社イナートガススクラバーはプレクーラーにベン チュリースクラバーを採用し, 燃焼ガスを高速化し海 水と接触させることで, 高い脱塵性能を発揮する. ま た，イナートガススクラバーには高い耐食性能が求め られることから，特殊なオーステナイト系ステンレス 鋼やゴムライニングなど，高度な防食設計を採用して いる.

\section{2 イナートガスファン}

イナートガスファンとは，その名の通りイナートガ スを貨物タンクへ送り込む装置である. イナートガス は体積で船舶の最大揚げ荷容量の $125 \%$ 相当以上の供 給率を要し，また各タンクにおいて最低 $200 \mathrm{mmH}_{2} \mathrm{O}$ の圧力を維持できなければならないため, イナートガ スファンは船毎の揚げ荷容量および船体構造を加味し た選定が必要となる．またイナートガスファンにも耐 食性能が求められるため, 当社のイナートガスファン はインペラーに二相ステンレス鋼を使用し，またファ ン内面塗料にはガラスフレーク塗料を採用した防食設 計となっている.

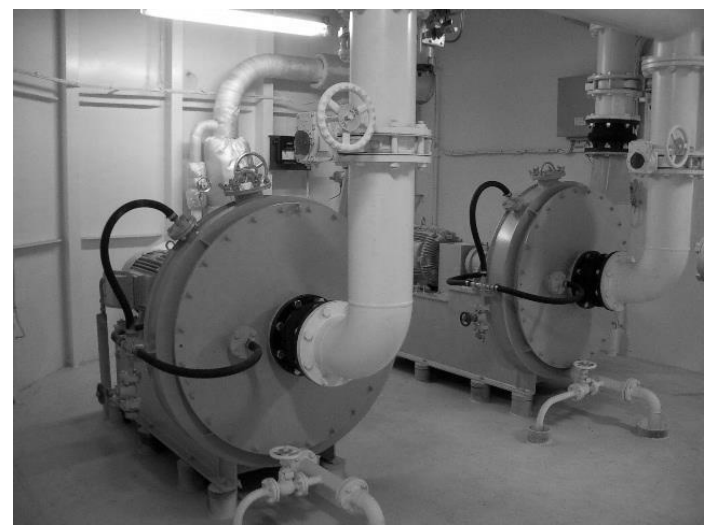

図 4. イナートガスファン

\section{3 デッキウォーターシール}

機関区域に貨物タンクからのガスの逆流を防止する ため，規則によりデッキウォーターシールの搭載が義 務付けられている.

デッキウォーターシールは内部に貯めたシール水に より貨物タンクからのガスの逆流を防止する装置であ るため, IGS 停止時にも動作させ続ける必要がある. そのため規則では 2 台の独立した海水ポンプを用意し， いずれかより常時給水を行うことが義務付けられてい る. また甲板上に設置されるため, シール水の凍結防 止としてヒーティングコイルが装備されている.

デッキウォーターシールには湿式, 半乾式, 乾式が 存在するが，当社では半乾式を採用している．また半
乾式にはベンチュリー方式とウォーター・ディスプレ イスメント方式があるが，当社はウォーター・ディス プレイスメント方式となる. IGS 非稼㗢時には，イナ 一トガス流入管の出口はシール水中に没している. IGS が稼㗢するとイナートガスにより，流入管を囲う 様に設けられた堰の内側のシール水が追い出され，そ れ以降流入したイナートガスは，シール水に接触しに くくなる. その後 IGS が停止すると，再びショートパ イプを通って堰内にシール水が戻り，シールの役割が 復活する仕組みとなっている.

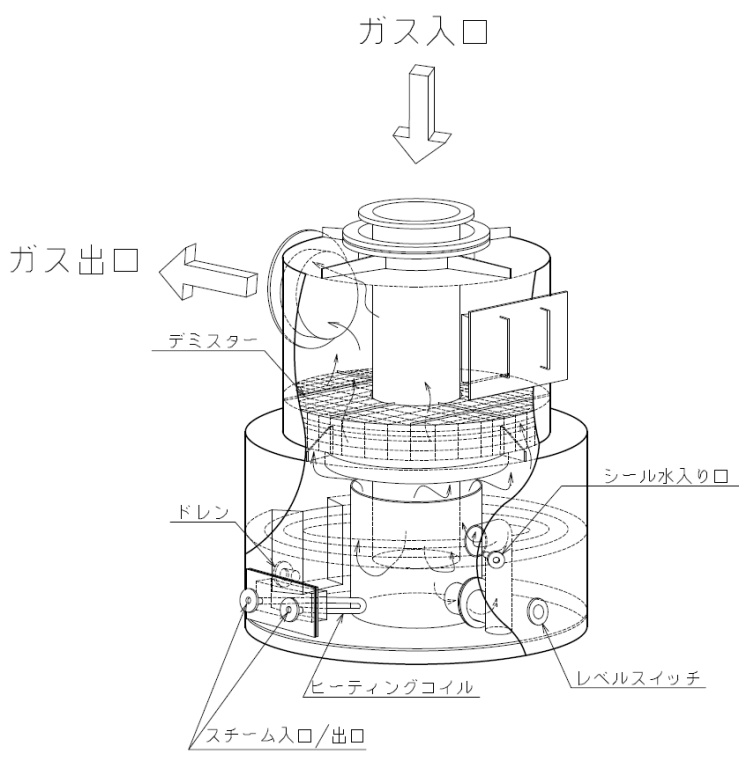

図 5. デッキウォーターシール

\section{4 酸素分析計}

規則にてイナートガス中の酸素濃度が体積で $5 \%$ 以 上含まれている場合には，イナートガスを貨物タンク に送ることはできず，大気中に放出しなければならな い. そのためイナートガスファン出口付近のガスライ ンにてイナートガスの酸素濃度の監視を行う目的とし て酸素分析計の設置が義務付けられている.

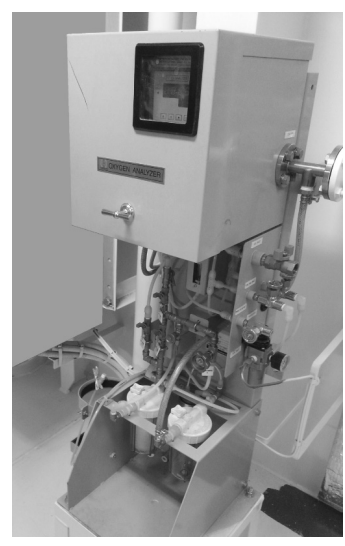

図 6. 酸素分析計 


\section{5 バルブ類}

IGS には多種多様なバルブが取り付けられており, 用途によって特殊な仕様となっているバルブも存在し ている. 当項ではIGS において重要な役割を持ってい るバルブを紹介する.

・アップテイクバルブ

ボイラーからイナートガススクラバーへの煙道入り 口に取り付けられるバルブであり, IGS が稼働してい ない時に燃焼ガスがイナートガススクラバーに入らな い様にシールするバルブである. 燃焼ガスは高温であ ることから，ラバーシートではなくメタルタッチ仕様 となっている. 但し, メタルタッチ仕様では完全な密 閉は不可能であるため, 煙道とは逆側から，エアーに よるシールも義務付けられている. アップテイクバル ブの材質には燃焼ガスによる腐食を防ぐため, 而腐食 性鋼が用いられる.

・圧力調節バルブ

当社ではメインバルブと呼称しており，イナートガ スを一定の圧力でタンクに供給するためのバルブであ る. イナートガスファン出口から貨物タンクに伸びる ガスライン上の, 機関室内隔壁近くに取り付けられる. メインバルブは後述の排気バルブと共に, バルブに取 り付けてあるポシシショナーにて開度調節し, 貨物タン クに送り込むイナートガス圧力のコントロールを行っ ている.

・排気バルブ

排気バルブはメインバルブへ向かうガスラインとは 別に, ファンネルへ向からライン上に取り付けられる, その名の通りイナートガス排気時に開放されるバルブ である. 排気バルブは貨物タンクへのイナートガス供 給前およびイナートガス中の酸素濃度が $5 \%$ を越えた 場合に開放される。.また，メインバルブと連動して制 御され余剩ガスを大気放出することにより，イナート ガス圧力の供給圧力をコントロールするために使用さ れる。

\section{2. $6 \mathrm{P} / \mathrm{V}$ ブレーカー}

$\mathrm{P} / \mathrm{V}$ ブレーカーは貨物タンクの過圧および負圧を 防ぐための装置である. 貨物タンクの保護装置であり イナートガスシステムの機器ではないが，搭載必須の 装置につき当社でも標準品として取り扱っている. 当 装置はサイズの異なる円筒を重㸚た 2 重構造になって おり，内部には液体が満たしてある。液体の比重を考 慮し，正しい水位に満たしておくことで，設定した圧 力にて過圧時にはガスを大気放出し, 負圧時には空気 を吸い込む. 甲板上に設置されるため, 凍結防止とし て液体には不凍液が使用される。

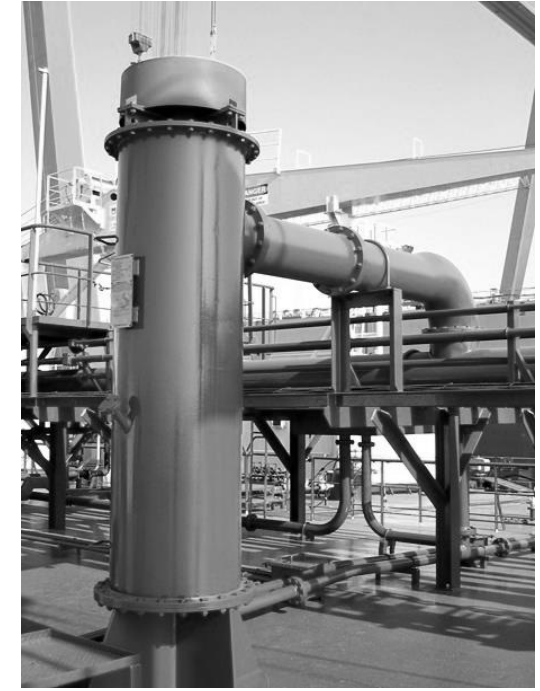

図 7.P/Vブレーカー

\section{7 トッピングアップ INERT GAS GENERATOR (TOP-UP IGG)}

航海中の気温の変化により貨物タンク内の圧力が低 下した際，イナートガスのトッピングアップ操作が必 要となる. トッピングアップに使用する少量のイナー トガスを生成するために，ボイラーの高負荷運転およ び追加の発電機や泠却ポンプの運転を必要とする IGS を稼働させるのは非効率である. そのためVLCC など ある程度大きなタンカーの場合には，トッピングアッ プ専用として小型の IGG が搭載されることも少なく ない.

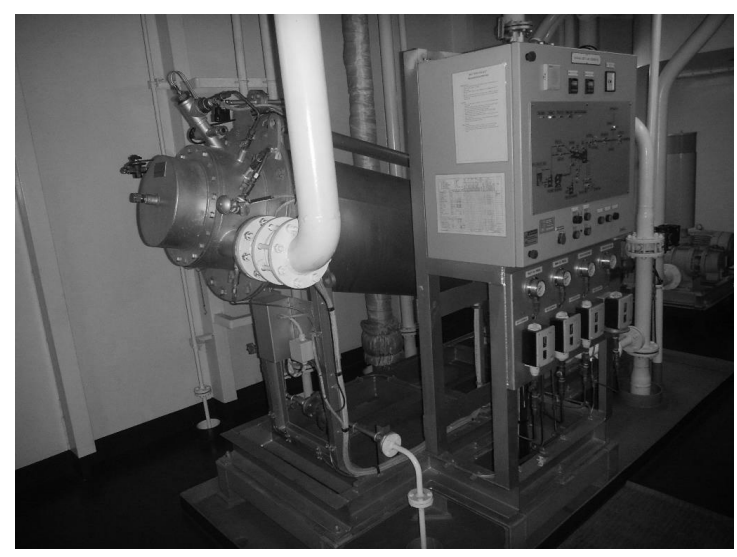

図 8. TOP-UP IGG

TOP-UP IGG は装備したオイルバーナーを用いて, 軽油またはA 重油を燃焼させて作られた少量の燃焼ガ スを組み込まれているスクラバーで泠却洗浄し，イナ ートガスを発生させる装置である，当社では IGS の オプション品として, $500 \mathrm{Nm}^{3} / \mathrm{h}$ の TOP-UP IGG を 取り扱っている. 


\section{3. 低硫黄燃料油焚きボイラーを想定した イナートガススクラバーの開発}

\section{1 燃料油硫黄含有量規制とイナートガススクラバー の SOx 除去率について}

2015 年 1 月以降，船舶が排出規制海域（ECA）内 で航行する際には, 船舶が使用寸る燃料の硫黄含有量 を $0.1 \%$ 以下に制限しなければならなくなり，2020 年 からは ECA 以外の全世界の海域でも $0.5 \%$ にき下げ ることになった．また今回の規則改正では，規制に適 合した燃料油を使用する代わりに排気ガス処理装置

（EGCS）を搭載して, 従来の硫黄含有量の燃料油を 使用し続けることも認めている.この EGCS に求めら れる脱硫性能は, $\mathrm{SO}_{2}(\mathrm{ppm}) / \mathrm{CO}_{2}(\mathrm{Vol} . \%)$ 比によって規 定されており, 燃料油の硫黄含有量が $0.5 \%$ のきは “21.7”，0.1\%のときは“4.3”となる.

一方，イナートガススクラバーは，大気污染防止が 目的ではなく, 主に $\mathrm{SO}_{2}$ や煤塵によるカーゴやタンク 類の保護を目的とし, スクラバーに要求される性能は MSC/Circ. 282 より“ $\mathrm{SO}_{2}$ の 90\%以上を除去し, 固体 を効果的に除去できるもの”とされている.この規則に は, ボイラーに使用する燃料油の硫黄含有量や $\mathrm{SO}_{2}$ 濃 度，イナートガススクラバーで処理されたガスの $\mathrm{SO}_{2} / \mathrm{CO}_{2}$ 比等の規定は無く, 硫黄含有量が $3.5 \%$ の場 合でも， $0.5 \%$ の場合でも $90 \%$ 以上の $\mathrm{SO}_{2}$ を除去する 必要があると解釈される.

\section{2 スクラバーの $\mathrm{SO}_{2}$ 濃度と除去率}

薬液を用いない一般的な一過式のスクラバー（オー プンループスクラバー) の場合, 一定量の洗浄水 (IGS の場合は海水) で吸収可能な $\mathrm{SO}_{2}$ の量は限られている ため, $\mathrm{SO}_{2}$ 濃度が濃くなると除去率は下がり, $\mathrm{SO}_{2}$ 濃 度が薄くなると除去率は上がる. そのため, $\mathrm{SO}_{2}$ の除 去率を上げるためには, 水量を増やしたりスクラバー を大きくして反応時間を増やしたりするなどの対策が 必要となる.

当社のイナートガススクラバーは, 燃料油の硫黄含 有量が $3.5 \%$ 以下に制限される以前の規制值である 4.5\%を想定した $\mathrm{SO}_{2}$ 濃度で設計しているため, $3.5 \%$ 以下の然料油を使用している現在の運用では，実際に は $98 \%$ 以上の $\mathrm{SO}_{2}$ 除去率を発揮している. 今後, 燃料 油の硫黄含有量が $0.5 \%$ 以下に強化されると,イナート ガススクラバーの $\mathrm{SO}_{2}$ 除去率は今よりも更に向上する.

図.9 に風量や散水量が同じ，女る条件のイナートガ ススクラバーで, 入口の $\mathrm{SO}_{2}$ 濃度を変えた場合の清水

（FW）と海水（SW）による $\mathrm{SO}_{2}$ 入口濃度と除去率 の関係を示す．このようにイナートガススクラバーの
運転条件が同じ場合でも， $\mathrm{SO}_{2}$ の濃度が変わると除去 率も変わることが確認できる.

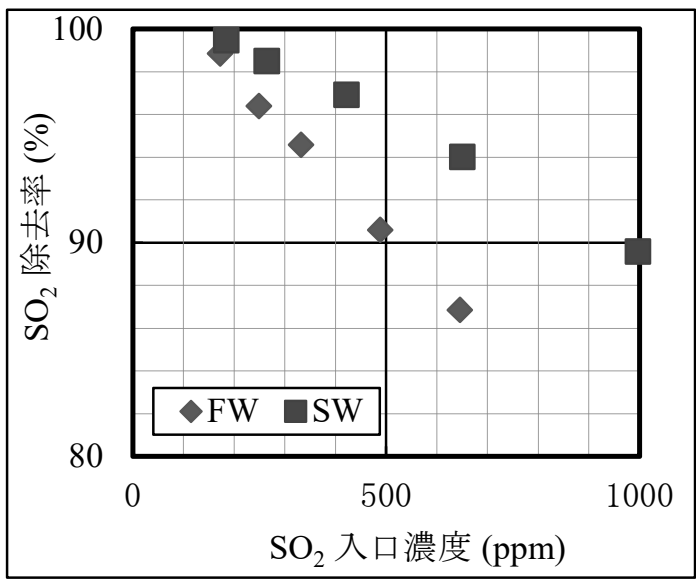

図 9. $\mathrm{SO}_{2}$ の入口濃度と除去率の関係

\section{3 低硫黄燃料油を想定したイナートガススクラバー}

ボイラーの燃料油が硫黄含有量 $0.5 \%$ 以下のものに 切り替わり，イナートガススクラバーは今までのもの を使用し続けた場合, イナートガス中の $\mathrm{SO}_{2}$ 濃度は更 に低くなり，カーゴやタンク類の保護効果も向上寸る と考えられるが，過剩設計との懸念もある. 燃料油中 硫黄含有量の上限が初めて定められたときの基準值で ある $4.5 \%$ と比べ, 2020 年からは一般海域でも $0.5 \%$ まで規制が強化されるため, それだけで $90 \%$ 近い $\mathrm{SO}_{2}$ の削減効果が認められる.

そこで当社では，イナートガススクラバーの設計条件 を, 燃料油の硫黄含有量が $0.5 \%$ に強化された際の $\mathrm{SO}_{2}$ 濃度を想定し， $\mathrm{SO}_{2}$ 除去率以外に燃焼ガス中に含まれ る煤塵の除去性能や高温ガスの冷却性能を総合的に判 断して, IGS スクラバーの最適化に取り組んでいる. その結果, $\mathrm{SO}_{2}$ の除去率や脱塵性能は既存のイナート ガススクラバーと変わらないまま, 体積を約 4 割, 散 水量を約 6 割削減することが可能となった. $0.5 \%$ 以下 の低硫黄然料油仕様のイナートガススクラバーとする ことで，装置の大きさが小さくなり，設置スペースに も余裕ができ, また水量も少なくなるため, ポンプ動 力等の運転コス卜削減にも繋がると考えている.

\section{著者紹介}

松林 広延

・株式会社カシワテック

設計第二部

不活性ガス装置グループ 